\title{
Bond Strength of Chlorine Peroxide
}

\author{
J. Plenge ${ }^{\dagger}$ \\ Department of Chemistry, University of California at Berkeley
}

\section{S. Kiihl}

Institut für Umweltphysik, Universität Heidelberg, Germany

\section{B. Vogel, R. Miiller, F. Stroh, and M. von Hobe}

Forschungszentrum Jülich, Institut für Stratosphärische Chemie (ICG I), 52425 Jülich, Germany

\author{
R. Flesch and E. Ruihl* \\ Institut für Physikalische Chemie, Universität Würzburg, Am Hubland, 97074 Würzburg, Germany
}

Received: December 23, 2004; In Final Form: June 8, 2005

The bond strength of chlorine peroxide $(\mathrm{ClOOCl})$ is studied by photoionization mass spectrometry. The experimental results are obtained from the fragmentation threshold yielding $\mathrm{ClO}^{+}$, which is observed at $11.52 \pm 0.025 \mathrm{eV}$. The $\mathrm{O}-\mathrm{O}$ bond strength $D^{\circ}$ is derived from this value in comparison to the first ionization energy of $\mathrm{ClO}$, yielding $D^{\circ}{ }_{298}=72.39 \pm 2.8 \mathrm{~kJ} \mathrm{~mol}^{-1}$. The present work provides a new and independent method to examine the equilibrium constant $K_{\text {eq }}$ for chlorine peroxide formation via dimerization of $\mathrm{ClO}$ in the stratosphere. This yields an approximation for the equilibrium constant in the stratospheric temperature regime between 190 and $230 \mathrm{~K}$ of the form $K_{\mathrm{eq}}=1.92 \times 10^{-27} \mathrm{~cm}^{3}$ molecules ${ }^{-1} \times \exp (8430 \mathrm{~K} / T)$. This value of $K_{\text {eq }}$ is lower than current reference data and agrees well with high altitude aircraft measurements within their scattering range. Considering the error limits of the present experimental results and the resulting equilibrium constant, there is agreement with previous works, but the upper limit of current reference values appears to be too high. This result is discussed along with possible atmospheric implications.

\section{Introduction}

$\mathrm{ClOOCl}$ is efficiently formed in the stratosphere from $\mathrm{ClO}$, if the temperature is low enough to permit dimerization. Three isomers of $\mathrm{Cl}_{2} \mathrm{O}_{2}$ are known $\left(\mathrm{ClOOCl}, \mathrm{ClClO}_{2}\right.$, and $\left.\mathrm{ClOClO}\right)$, of which $\mathrm{ClOOCl}$ is the most stable one. ${ }^{1,2}$ Therefore, dimerization of $\mathrm{ClO}$ yields preferably chlorine peroxide $\mathrm{ClOOCl}$, whereas the other isomers are formed with considerably lower efficiency. ${ }^{3,4} \mathrm{ClOOCl}$ is a key compound for the understanding of strong stratospheric ozone loss in the cold stratosphere, which is regularly observed in polar spring. ${ }^{5,6}$ The isomer chlorine peroxide $\mathrm{ClOOCl}$ is the key species in the major ozone loss cycle under polar stratospheric conditions: ${ }^{5-7}$

$$
\begin{gathered}
2 \mathrm{ClO}+\mathrm{M} \rightleftharpoons \mathrm{ClOOCl}+\mathrm{M} \\
\mathrm{ClOOCl}+h v \rightarrow \mathrm{ClOO}+\mathrm{Cl} \\
\mathrm{ClOO}+\mathrm{M} \rightarrow \mathrm{Cl}+\mathrm{O}_{2}+\mathrm{M} \\
2\left(\mathrm{Cl}+\mathrm{O}_{3} \rightarrow \mathrm{ClO}+\mathrm{O}_{2}\right)
\end{gathered}
$$

net: $2 \mathrm{O}_{3}+h v \rightarrow 3 \mathrm{O}_{2}$

Reactions 2 and 3 proceed probably in a concerted manner,

\footnotetext{
* Corresponding author. Telephone: $++49-931-888$ 6300. Fax: ++49 931-888 6302. E-mail: eruehl@phys-chemie.uni-wuerzburg.de.

$\dagger$ Present address: Institut für Physikalische Chemie, Universität Würzburg, Am Hubland, 97074 Würzburg, Germany.
}

where the intermediate $\mathrm{ClOO}$ is produced with sufficient energy so that it likely dissociates spontaneously under stratospheric conditions. ${ }^{8}$

The ground-state geometry of $\mathrm{ClOOCl}$ has been reported by Birk et al., ${ }^{9}$ which has been recently questioned based on coupled cluster calculations. ${ }^{10}$ In particular, the $\mathrm{O}-\mathrm{O}$ bond length is found to be shorter than in previous experimental work.

The bond strength of $\mathrm{ClOOCl}$ at $298 \mathrm{~K}$ has been reported before. The values range between $69 \pm 3 \mathrm{~kJ}$ and $81.6 \pm 2.9 \mathrm{~kJ}$ $\mathrm{mol}^{-1} \cdot{ }^{11,12} \mathrm{Cox}$ and Hayman report $72.5 \pm 3 \mathrm{~kJ} \mathrm{~mol}^{-1}{ }^{13}$ This bond strength as well as the equilibrium constant for $\mathrm{ClOOCl}$ formation according to eq 1 are crucial quantities with respect to the importance of the ozone loss mechanism shown in eqs $1-5$. Small changes in $\mathrm{ClO}-\mathrm{OCl}$ bond strength may significantly change the equilibrium of eq 1 in the stratosphere. Moreover, discrepancies between measurements of chlorine oxides in the stratosphere and model predictions are reported which may possibly be connected with uncertainties in stratospheric chlorine chemistry. ${ }^{14,15}$ Recent field measurements by von Hobe et al. ${ }^{16}$ and Stimpfle et al. ${ }^{17}$ indicate that there are indeed discrepancies in the equilibrium constant for $\mathrm{ClOOCl}$ formation.

The motivation for the present work is the importance of $\mathrm{ClO}$ chemistry in the polar stratosphere including existing uncertainties that are related to the dimerization of $\mathrm{ClO}$. We report the $\mathrm{ClO}-\mathrm{OCl}$ bond strength using photoionization mass spectrometry as an alternative laboratory approach compared to previous 
works, where the dimerization equilibrium of $\mathrm{ClO}$ was investigated. ${ }^{11-13}$

\section{Experimental Section}

The experimental setup consists of the following components: (i) a flow tube for $\mathrm{ClO}$ and $\mathrm{ClOOCl}$ production; (ii) a tunable vacuum-ultraviolet (VUV) radiation source (laserproduced plasma, pulse length $=25 \mathrm{~ns}, \sim 10^{9}$ photons $/ \mathrm{s}$ at a bandwidth of $0.8 \mathrm{~nm}$ ) between $8 \mathrm{eV} \leq E \leq 25 \mathrm{eV}$ photon energy; (iii) a time-of-flight mass spectrometer (TOF) for cation separation and detection. ${ }^{4} \mathrm{ClO}$ is generated in the flow tube by the reaction: $\mathrm{Cl}+\mathrm{OClO} \rightarrow 2 \mathrm{ClO}$, using a gas mixture of $5 \%$ $\mathrm{Cl}_{2}$ in $\mathrm{He}$ for $\mathrm{Cl}$ production in a microwave discharge at typically $p=5 \mathrm{hPa}$. The $\mathrm{OClO}$ source has been described before. ${ }^{18}$ Chlorine peroxide is efficiently produced by cooling the flow tube to $170 \mathrm{~K}$, as reported in previous work. ${ }^{4} \mathrm{We}$ derive from our prior photolysis work the contribution of $\mathrm{ClClO}_{2}$ to $\mathrm{Cl}_{2} \mathrm{O}_{2}$ to be $17 \pm 2 \%$, whereas the remaining $83 \pm 2 \%$ contribution is due to $\mathrm{ClOOCl} .{ }^{4}$ It is assumed that the contribution of $\mathrm{ClClO}_{2}$ is essentially due to residual humidity in the cold flow system, which promotes the formation of this species via heterogeneous reactions. The formation of $\mathrm{Cl}_{2} \mathrm{O}_{3}$ is avoided by titrating the $\mathrm{OClO}$ with atomic chlorine. Thus, no mass signals from $\mathrm{Cl}_{2} \mathrm{O}_{3}{ }^{+}$ $(\mathrm{m} / \mathrm{z}=118,120,122)$ are observed in photoionization mass spectra. Further, no evidence from mass signals pointing to the formation of higher chlorine oxides in the flow tube is found (cf. ref 19). The gaseous sample emerges from the flow tube into a high vacuum recipient. It is ionized in the ionization region of the TOF by tunable VUV-radiation at $p \leq 10^{-3} \mathrm{~Pa}$, i.e., under collision-free conditions. The ionization and fragmentation thresholds of selected mass channels are obtained by scanning the photon energy while measuring the cation intensity. The intensity of the ionizing VUV-radiation is measured simultaneously, so that photoionization mass spectra as well as photoion yields are reliably normalized to the VUV photon flux. The absolute photon energy scale is established by using the autoionization of molecular oxygen as well as rare gases. ${ }^{20}$

\section{Results and Discussion}

Bond Strength of $\mathrm{ClO}-\mathrm{OCl}$. Photoionization mass spectrometry is used to determine the $\mathrm{O}-\mathrm{O}$ bond strength of $\mathrm{ClO}-$ $\mathrm{OCl}$. This is accomplished by measuring the ionization energy of $\mathrm{ClO}$ and the fragmentation threshold of $\mathrm{ClO}^{+}$formation from $\mathrm{ClOOCl}$. The energy difference between both quantities yields the $\mathrm{ClO}-\mathrm{OCl}$ bond strength.

The ionization energy of $\mathrm{ClO}(\mathrm{IE}(\mathrm{ClO}))$ is obtained from the $\mathrm{ClO}^{+}$photoion yield of the room-temperature $\mathrm{ClO}$ sample, where no chlorine peroxide is present in the flow tube:

$$
\mathrm{ClO}+h v \rightarrow \mathrm{ClO}^{+}+\mathrm{e}^{-}
$$

as shown in Figure 1a. This yields $\operatorname{IE}(\mathrm{ClO})=10.85 \pm 0.013$ $\mathrm{eV}$. The error limit of the threshold energy is determined from the experimental uncertainty, where the ion intensity rises above the noise level, as follows from Figure 1a. Each data point corresponds to the sum of repeated scans of the $\mathrm{ClO}^{+}$yield as a function of photon energy. This measurement confirms our earlier work, but the error limit is significantly reduced. ${ }^{21}$ Note that Thorn et al. have reported a somewhat higher ionization threshold value of $10.885 \pm 0.016 \mathrm{eV} .^{22}$ This discrepancy is essentially the result of a different way of determining the ionization threshold. We use throughout this work the approach outlined by Traeger and McLoughlin, ${ }^{23}$ where the threshold energy is found by linear extrapolation of the ion intensity right

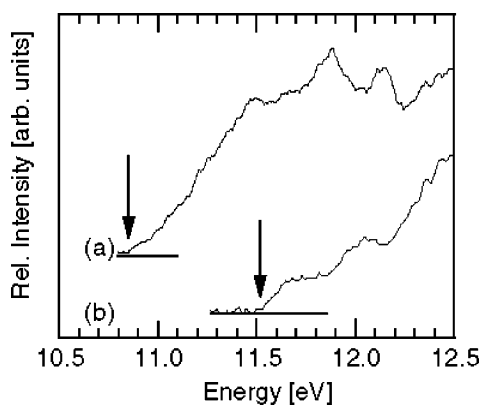

Figure 1. Photoion yield of $\mathrm{ClO}^{+}$recorded at different experimental conditions: (a) $T=298 \mathrm{~K}$; (b) $T=170 \mathrm{~K}$. The arrows indicate the threshold energies. The horizontal lines mark the zero level of cation intensity.

above the onset to the pre-threshold level, similar to previous work. ${ }^{24}$ This aspect is of central importance to the present work, where differences in threshold energies are used to determine the $\mathrm{ClO}-\mathrm{OCl}$ bond strength. These must be determined exactly in the same way in order to avoid artifacts that may come from different ways to determine ionization or fragmentation thresholds.

The appearance energy of $\mathrm{ClO}^{+}$from $\mathrm{ClOOCl}$ is measured by cooling the flow tube to $T=170 \mathrm{~K}$. This yields an increased threshold energy relative to that of neat $\mathrm{ClO}$, corresponding to $11.52 \pm 0.025 \mathrm{eV}$ (see Figure 1b). This threshold is determined in the same way as the ionization energy of $\mathrm{ClO}$, indicating that $\mathrm{ClO}$ is efficiently bound in $\mathrm{Cl}_{2} \mathrm{O}_{2}$, where predominantly $\mathrm{ClOOCl}$ is formed. ${ }^{4}$ Although, $\mathrm{ClOOCl}$ represents $83 \%$ of the $\mathrm{Cl}_{2} \mathrm{O}_{2}$ sample, as outlined in the previous section, it is important to find evidence whether exclusively this majority species contributes to the experimental threshold energy. The photoion yield of $\mathrm{ClO}^{+}$is characterized by two distinct steps above the onset energy. These steps occur at the threshold $(E=11.52$ $\mathrm{eV}$ ) and near $11.84 \mathrm{eV}$, respectively. The energy difference of $\approx 0.32 \mathrm{eV}$ is too large to be due to any vibrational fine structure of the neutral (cf. ref 25) or the cation. It is rather assumed that either close lying direct ionization processes from outer occupied orbitals, ${ }^{26}$ or autoionization features contribute to the structured photoion yield of $\mathrm{ClO}^{+}$in the threshold regime.

The origin of $\mathrm{ClO}^{+}$that contributes to this threshold value is discussed in the following with respect to other channels that may possibly be active at the threshold energy: First, $\mathrm{ClOOCl}$ is formed efficiently upon dimerization of $\mathrm{ClO}$, corresponding to chlorine peroxide formation, at low temperature. ${ }^{4}$ In this case, the appearance energy of $\mathrm{ClO}^{+}$is due to fragmentation from $\mathrm{ClOOCl}^{+}$, so that this value can be used to determine the bond strength of $\mathrm{ClO}-\mathrm{OCl}$. However, other $\mathrm{Cl}_{x} \mathrm{O}_{y}$ minority species may also contribute to the $\mathrm{ClO}^{+}$threshold. The appearance energy of the process $\mathrm{ClClO}_{2}+h v \rightarrow \mathrm{ClO}^{+}+\mathrm{Cl}+\mathrm{O}+\mathrm{e}^{-}$ is calculated to be $14.28 \mathrm{eV}$ (cf. data from ref 27). Even if instead of the neutrals $\mathrm{Cl}+\mathrm{O}$ the molecular fragment $\mathrm{ClO}$ is formed upon dissociative photoionization, one derives a threshold value of $11.49 \mathrm{eV}$, which is slightly below the value of $11.52 \pm 0.025 \mathrm{eV}$, that is deduced from Figure 1b. Thus, the threshold energies of these processes starting from $\mathrm{ClOOCl}$ and $\mathrm{ClClO}_{2}$ are quite similar to each other, so that they will be difficult to distinguish, if they occur with the same intensity. Evidently, this is not the case for the following reasons: (i) $\mathrm{ClClO}_{2}$ is only a minority species in the sample; (ii) both isomers should have the same fragmentation cross section in the threshold regime; (iii) the fragmentation threshold starting from $\mathrm{ClClO}_{2}$ would imply that the cation undergoes massive rearrangement processes after vertical excitation, which appears to be unlikely at the threshold energy. In contrast, the process 
starting from $\mathrm{ClOOCl}$ corresponds to a rupture of the $\mathrm{ClO}-$ $\mathrm{OCl}^{+}$bond. Contributions to the $\mathrm{ClO}^{+}$yield from higher chlorine oxides are ruled out, as pointed out in the previous section. Furthermore, contributions to the $\mathrm{ClO}^{+}$threshold from the reactant $\mathrm{OClO}$ are ruled out, since the fragmentation threshold is found at $13.40 \pm 0.04 \mathrm{eV} .{ }^{28}$ Therefore, one expects for the majority species $\mathrm{ClOOCl}$ a clearly visible threshold that leads to $\mathrm{ClO}^{+}$formation at $11.52 \mathrm{eV}$ (cf. Figure 1b), which is assigned to dissociative photoionization of $\mathrm{ClOOCl}$ :

$$
\mathrm{ClOOCl}+h v \rightarrow \mathrm{ClO}^{+}+\mathrm{ClO}+\mathrm{e}^{-}
$$

The difference in threshold energies between processes 7 and 6 gives directly the bond dissociation energy of $\mathrm{ClOOCl}$, using the stationary electron convention and by considering thermal effects. ${ }^{23}$ First, we correct the experimental results to $T=0 \mathrm{~K}$, using the experimental value from Figure 1a: $\operatorname{IE}(\mathrm{ClO})=$ $10.85 \pm 0.013 \mathrm{eV}$. The heat of formation of $\mathrm{ClO}$ is wellknown: $\Delta_{\mathrm{f}}{H^{\circ}}_{0}(\mathrm{ClO})=101.03 \pm 0.1 \mathrm{~kJ} \mathrm{~mol}^{-1} .^{29}$ This yields together with $\mathrm{IE}(\mathrm{ClO}): \Delta_{\mathrm{f}} H^{\circ}{ }_{0}\left(\mathrm{ClO}^{+}\right)=1147.9 \pm 1.3 \mathrm{~kJ} \mathrm{~mol}^{-1}$. This value is somewhat smaller than that reported by Thorn et al., ${ }^{22}$ since they used a larger value for the first ionization energy of $\mathrm{ClO}$, as mentioned above. The appearance energy yielding $\mathrm{ClO}^{+}$from $\mathrm{ClOOCl}\left(\mathrm{AE}\left(\mathrm{ClO}^{+} / \mathrm{ClOOCl}\right)\right)$ (see Figure $\left.1 \mathrm{~b}\right)$ has been recorded at $T=170 \mathrm{~K}$. This value is corrected to $T=$ $0 \mathrm{~K}$ according to ${ }^{22,23}$

$$
\begin{aligned}
\mathrm{AE}_{0}\left(\mathrm{ClO}^{+} / \mathrm{ClOOCl}\right)=\mathrm{AE}_{170}\left(\mathrm{ClO}^{+} / \mathrm{ClOOCl}\right)+ \\
{\left[H_{170}-H_{0}\right]-2.5 R T }
\end{aligned}
$$

The thermal correction is obtained from the heat capacity estimates of $\mathrm{ClOOCl}$ similar to calculations by Abramowitz and Chase ${ }^{29}$ and the most recent JANAF compilation. ${ }^{30}$ Instead of the data from these references we use slightly different, rounded vibrational frequencies, which are based on more recent experimental work by Jacobs et al. ${ }^{25}$ including vibrations communicated in earlier work: $v_{1}=754 \mathrm{~cm}^{-1}, v_{2}=543 \mathrm{~cm}^{-1}$, $v_{3}=320 \mathrm{~cm}^{-1}, v_{4}=127 \mathrm{~cm}^{-1}, v_{5}=648 \mathrm{~cm}^{-1}$, and $v_{6}=419$ $\mathrm{cm}^{-1}$. These values consider the dominant abundance of the ${ }^{35} \mathrm{Cl}$ isotopomer and appear to be more reliable than earlier estimates (cf. ref 29). We note that the difference in thermal correction between both approaches is of the order of $0.055 \mathrm{~kJ}$ $\mathrm{mol}^{-1}$ for the correction from 170 to $0 \mathrm{~K}$. However, this difference increases more significantly to $0.2 \mathrm{~kJ} \mathrm{~mol}^{-1}$ for the thermal correction from 0 to $298 \mathrm{~K}$ (see below).

The present thermal correction yields $\mathrm{AE}_{0}\left(\mathrm{ClO}^{+} / \mathrm{ClOOCl}\right)$ $=11.555 \pm 0.025 \mathrm{eV}$. Ionic fragmentation of $\mathrm{ClOOCl}$ yields $\mathrm{ClO}^{+}+\mathrm{ClO}$ (cf. eq 7). The sum of the heats of formation of these products is: $\Delta_{\mathrm{f}} H^{\circ}{ }_{0}\left(\mathrm{ClO}^{+}\right)+\Delta_{\mathrm{f}} H^{\circ}{ }_{0}(\mathrm{ClO})=1248.93 \pm$ $1.36 \mathrm{~kJ} \mathrm{~mol}^{-1}$. One obtains from this value by subtracting $\mathrm{AE}_{0}$ $\left(\mathrm{ClO}^{+} / \mathrm{ClOOCl}\right)$ the heat of formation of $\mathrm{ClOOCl}: \Delta_{\mathrm{f}} \mathrm{H}^{\circ}{ }_{0}$ $(\mathrm{ClOOCl})=134.07 \pm 2.8 \mathrm{~kJ} \mathrm{~mol}^{-1}$. This value compares well to previous experimental work, ${ }^{12,13}$ and theoretical studies that range from 123.1 to $143.2 \mathrm{~kJ} \mathrm{~mol}^{-1} .27,31-33$

The bond strength of chlorine peroxide at $T=0 \mathrm{~K}$ is obtained from

$$
D_{0}^{\circ}(\mathrm{ClO}-\mathrm{OCl})=2 \Delta_{\mathrm{f}} H_{0}^{\circ}(\mathrm{ClO})-\Delta_{\mathrm{f}} H_{0}^{\circ}(\mathrm{ClOOCl})
$$

yielding $D_{0}^{\circ}(\mathrm{ClO}-\mathrm{OCl})=67.99 \pm 2.8 \mathrm{~kJ} \mathrm{~mol}^{-1}$. Note that this value is similar to results from earlier theoretical work, where $79.16 \mathrm{~kJ} \mathrm{~mol}^{-1}$ are derived with a considerable error limit of $\pm 12.5-20.9 \mathrm{~kJ} \mathrm{~mol}^{-1}{ }^{5} \mathrm{D}_{0}^{\circ}(\mathrm{ClO}-\mathrm{OCl})$ is corrected to $T=$ $298 \mathrm{~K}$ so that it can be compared to previous works. ${ }^{11-13}$ This is accomplished by using $\Delta_{\mathrm{f}} H^{\circ}{ }_{298}(\mathrm{ClO})=101.63 \pm 0.1 \mathrm{~kJ}$

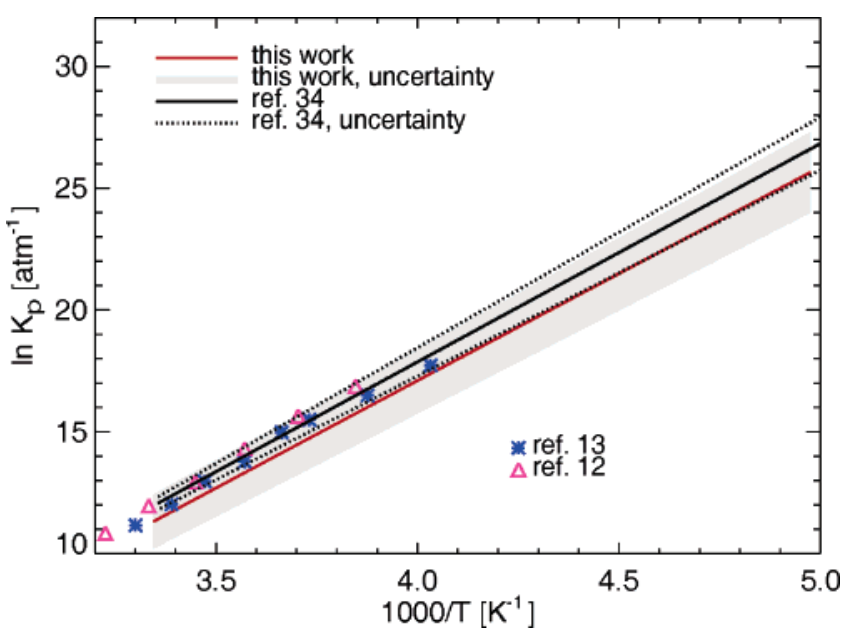

Figure 2. Temperature dependence of the equilibrium constant $K_{\mathrm{p}}$ of reaction 1 as a function of the reciprocal temperature. Experimental results from laboratory work, ${ }^{12,13}$ the recommended values from ref 34 , and results from this work are included.

TABLE 1: Comparison of the ClO-OCl Bond Strength at $T=298 \mathrm{~K}: D^{\circ}{ }_{298}(\mathrm{ClO}-\mathrm{OCl})$ Derived from Experimental Work

\begin{tabular}{lc}
\hline reference & $D^{\circ}{ }_{298}(\mathrm{ClO}-\mathrm{OCl}), \mathrm{kJ} \mathrm{mol}^{-1}$ \\
\hline Basco and Hunt $^{11}$ & $69 \pm 3$ \\
Nickolaisen et al. $^{12}$ & $81.6 \pm 2.9$ \\
Cox and Hayman & $72.5 \pm 3$ \\
this work & $72.39 \pm 2.8$
\end{tabular}

$\mathrm{mol}^{-1} .^{29,30} \Delta_{\mathrm{f}} H^{\circ}{ }_{298}(\mathrm{ClOOCl})$ is obtained from $\Delta_{\mathrm{f}} H^{\circ}{ }_{0}(\mathrm{ClOOCl})$ along with thermal corrections as outlined above. ${ }^{23,25,29,30} \mathrm{We}$ derive from this $\Delta_{\mathrm{f}} H^{\circ}{ }_{298}(\mathrm{ClOOCl})=130.87 \pm 2.8 \mathrm{~kJ}$ mol- ${ }^{1}$. Finally, we obtain according to eq 9 for $T=298 \mathrm{~K}$ : $D^{\circ}{ }_{298}$ $(\mathrm{ClO}-\mathrm{OCl})=72.39 \pm 2.8 \mathrm{~kJ} \mathrm{~mol}^{-1}$. This value compares well with previous works (see Table 1). Small, but significant discrepancies compared to the current JPL-evaluation ${ }^{34}$ will be discussed in greater detail in the following section.

Atmospheric Implications. From the experimental bond dissociation energy of chlorine peroxide derived from the present work, we can calculate the equilibrium constant $K_{\text {eq }}$ for reaction 1 , which is expressed in terms of the reaction entropy $\Delta_{\mathrm{r}} S$ and enthalpy $\Delta_{\mathrm{r}} H$ :

$$
K_{\text {eq }}=\frac{R T}{N_{\mathrm{A}}} \mathrm{e}^{\Delta_{\mathrm{r}} S / R} \mathrm{e}^{-\Delta_{\mathrm{r}} H / R T}
$$

where $N_{\mathrm{A}}$ is the Avogadro constant and $R$ is the universal gas constant. The temperature dependence of $\Delta_{\mathrm{r}} S$ and $\Delta_{\mathrm{r}} H$ is considered in order to obtain accurate results over a wide temperature range. $\Delta_{\mathrm{r}} S(T)$ is derived from third law entropies of $\mathrm{ClO}$ and $\mathrm{ClOOCl}$, as described by Chase, ${ }^{30}$ using the vibrational frequencies derived by Jacobs et al. (cf. previous section). ${ }^{25} \Delta_{\mathrm{r}} H(T)$ is equivalent to the bond dissociation energy of $\mathrm{ClOOCl}$ calculated from $\Delta_{\mathrm{f}} H^{\circ}(\mathrm{ClO})$ and $\Delta_{\mathrm{f}} H^{\circ}(\mathrm{ClOOCl})$ (see eq 9 ) using the thermal correction to account for its temperature dependence. ${ }^{29,30}$

Figure 2 shows a van't Hoff plot of the equilibrium constant $K_{\mathrm{p}}$ as a function of $T^{-1} . K_{\mathrm{p}}\left[\mathrm{atm}^{-1}\right]$ is derived from $K_{\mathrm{eq}}\left[\mathrm{cm}^{3} /\right.$ molecule] using eq 10 , where $K_{\mathrm{p}}=K_{\text {eq }}(T) /(R T)$. Thus, the present results can be directly compared to earlier works, which are also included in Figure 2. ${ }^{12,13,34}$ The error limits of $K_{\mathrm{p}}$ are directly determined by the error limit of the $\mathrm{ClO}-\mathrm{OCl}$ bond strength given above. This is due to the fact that the uncertainty of $\Delta_{\mathrm{r}} S$ is negligible compared to the uncertainty of $\Delta_{\mathrm{r}} H$ (cf. ref 30). The present value of $K_{\text {eq }}$ is lower over the entire temperature 


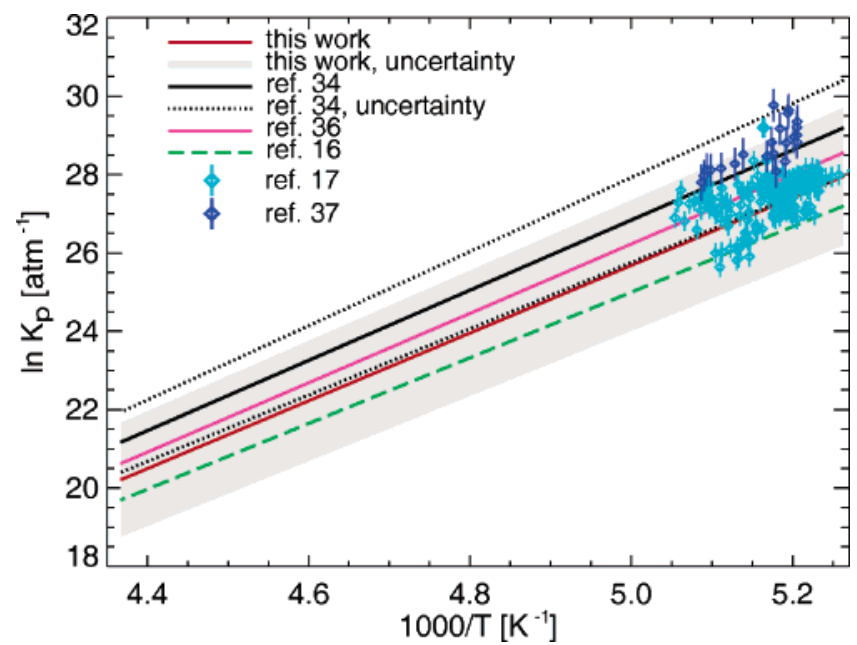

Figure 3. Temperature dependence of the equilibrium constant $K_{\mathrm{p}}$ of reaction 1 as a function of the reciprocal temperature in the regime of stratospheric temperatures. Experimental results from field measurements, ${ }^{16,17,36}$ the recommended values from ref 34 , and results from this work are included. The measurements from refs 17 and 37 were conducted in the Arctic winter 1999/2000. They are shown for $p<$ $100 \mathrm{hPa}$ (see diamonds with error bars).

range shown in Figure $2(200 \mathrm{~K}<T<300 \mathrm{~K})$ than $K_{\text {eq }}$ given by the current JPL evaluation ${ }^{34}$ and previous laboratory measurements. ${ }^{12}$ Good agreement is found with results reported by Cox and Hayman. ${ }^{13} K_{\text {eq }}$ from the present work practically coincides with the lower limit of the current JPL recommendation. ${ }^{34}$ These discrepancies lie within the uncertainty range of the present results. This suggests that there is general agreement between the different $K_{\text {eq }}$ values. However, the present results allow us to exclude the upper uncertainty limit of the JPL recommendation for $K_{\text {eq }}{ }^{34}$ Furthermore, the difference between the JPL recommendation for $K_{\text {eq }}$ and the values reported here has significant implications for the equilibrium partitioning of $\mathrm{ClO}$ and $\mathrm{ClOOCl}$ in the stratosphere, where simulated mixing ratios of $\mathrm{ClO}$ for night time conditions are extremely sensitive to the exact value of the bond strength of chlorine peroxide. ${ }^{16}$ Specifically, for a given amount of active chlorine (see below) at $T=190 \mathrm{~K}$, the equilibrium $\mathrm{ClO}$ concentrations calculated from the two different $K_{\text {eq }}$ values, i.e., from ref 34 and this work, differ by up to a factor of 2 .

The overall temperature dependence of $K_{\text {eq }}$ is obtained by fitting the results derived from eq 10 over the temperature range between 150 and $400 \mathrm{~K}$ (see Figure 2). This can be expressed as

$$
K_{\mathrm{eq}}=1.61 \times 10^{-27}\left(\frac{T}{300}\right)^{-0.29} \mathrm{e}^{8480 / T}
$$

However, in stratospheric chemistry models usually a parametrization of the form $K_{\text {eq }}=A \times \exp (B / T)$ is used. ${ }^{34} \mathrm{We}$ approximate the results from eq 10 and 11 in the typical temperature range of the polar stratosphere between 190 and $230 \mathrm{~K}$ using $A=1.92 \times 10^{-27} \mathrm{~cm}^{3}$ molecule ${ }^{-1}$ and $B=8430$ $\mathrm{K}$. This is compared in Figure 3 to the recommended JPL value ${ }^{34}$ and various estimates based on night-time field measurements, employing the chemical-conversion resonance-fluorescence technique, ${ }^{35}$ where results from refs $16,17,36,37$ are included.

At night time, when photolysis effects are negligible and the probed air parcels can be assumed to be in a thermal equilibrium. $K_{\text {eq }}$ is deduced from observed $\mathrm{ClO}$ and $\mathrm{ClOOCl}$ stratospheric concentrations, using

$$
K_{\mathrm{eq}}=\frac{[\mathrm{ClOOCl}]_{\text {night }}}{[\mathrm{ClO}]_{\text {night }}^{2}}
$$

The analysis of in situ $\mathrm{ClO}$ high altitude aircraft measurements by Avallone and Toohey and estimated $\mathrm{ClOOCl}$ mixing ratios, assuming full chlorine activation, yield a somewhat higher equilibrium constant than derived from the present work. ${ }^{36}$ This value of $K_{\mathrm{eq}}$ is still significantly lower than the value reported in ref 34. Results based on in situ $\mathrm{ClO}$ and $\mathrm{ClOOCl}$ measurements for solar zenith angles SZA $>95^{\circ}$, conducted in the Arctic stratosphere on board the high altitude aircraft ER-2 in winter 1999/2000 by Stimpfle et al., ${ }^{17}$ agree with the results of the present work. Von Hobe et al. found an even lower value for $K_{\text {eq }}$ based on in situ $\mathrm{ClO}$ and $\mathrm{ClOOCl}$ aircraft measurements conducted in the Arctic winter 2002/2003. ${ }^{16}$ These aircraft measurements ${ }^{16,17,36}$ generally confirm the equilibrium constant of the present work within their scatter range and provide strong evidence that the current recommendation ${ }^{34}$ slightly overestimates $K_{\text {eq. }}$. On the other hand, another evaluation, ${ }^{37}$ that is based on $\mathrm{ClO}$ measurements which were obtained from a balloonborne instrument, launched on March 1, 2000, before sunrise from Esrange $\left(67.5^{\circ} \mathrm{N}, 21.0^{\circ} \mathrm{E}\right)$ near Kiruna, North Sweden, supports slightly higher values for $K_{\mathrm{eq}}$ than the recommended value. Specifically, night-time $\mathrm{ClO}$ mixing ratios measured during the ascent between 96 and $99^{\circ}$ SZA are used in the previous analysis. ${ }^{37}$ The corresponding $\mathrm{ClOOCl}$ mixing ratios were estimated from $\mathrm{ClO}$ daylight measurements based on the assumption that the total amount of reactive chlorine $\mathrm{ClO}_{x}$ is given by

$$
\mathrm{ClO}_{x}=\mathrm{ClO}+2 \mathrm{ClOOCl}
$$

and that during daylight $\left(\mathrm{SZA}<88^{\circ}\right)$ the air parcels are in a photochemical steady state with the $\mathrm{ClOOCl}$ photolysis (eq 2) which is progressing much faster than the thermal decay (eq 1). Then one obtains

$$
[\mathrm{ClOOCl}]_{\mathrm{day}} \approx \frac{k_{f}[\mathrm{ClO}]_{\mathrm{day}}{ }^{2} M}{J}
$$

Here, $k_{\mathrm{f}}$ is the rate constant for the $\mathrm{ClOOCl}$ formation, which is taken from ref 34 (see eq 1), $J$ is the photolysis rate constant (see eq 2) derived from absorption cross sections recommended by Burkholder et al., ${ }^{38}$ and $M$ is the air density. For pairs of $[\mathrm{ClO}]_{\text {day }}$ and $[\mathrm{ClO}]_{\text {night }}$ taken on the same levels of potential temperature $\Theta$, where $\Theta=T(1000 / p)^{R / c_{p}}$, with the atmospheric pressure $p$ measured in $\mathrm{hPa}$ and the molar heat capacity of air $c_{p},{ }^{39}$ conservative $\mathrm{ClO}_{x}$ concentrations $\left[\mathrm{ClO}_{x}\right]$ can be estimated over time scales for which the impact of heating or cooling can be neglected. This corresponds to adiabatic conditions, where in the atmosphere air parcels remain on a level of constant potential temperature. Thus, using eqs $12-14$ gives

$$
K_{\mathrm{eq}}=\frac{\left[\mathrm{ClO}_{x}\right]-[\mathrm{ClO}]_{\text {night }}}{2[\mathrm{ClO}]_{\text {night }}^{2}}
$$

with an uncertainty of $40-45 \%$ for $K_{\text {eq }}$ calculated by error propagation. $\mathrm{ClO}$ mixing ratios were averaged in $\Theta$ intervals of $\pm 5 \mathrm{~K}$ in the range $380 \mathrm{~K} \leq \Theta \leq 485 \mathrm{~K}$. This is equivalent to $40 \mathrm{hPa} \leq p \leq 98 \mathrm{hPa}$. We note that calculations of backward trajectories show that the origin of the air masses sampled in the balloon ascent and descent are located sufficiently close together so that it is ruled out that different air masses were probed. ${ }^{37}$ Reasons for the discrepancy between balloon observa- 
tions ${ }^{37}$ and aircraft observations, ${ }^{16,17,36}$ in particular those carried out in the same winter, ${ }^{17}$ are currently unknown. However, it appears to be possible that the high altitude aircraft measurements, ${ }^{17}$ that were taken in early winter 1999/2000 (between 000114 and 000203), do not reflect the same amount of chlorine activation than the balloon measurements that were conducted in the beginning of March 2000. ${ }^{37}$ Specifically, model simulations indicate that at the end of February 2000 chorine reactivation occurred. ${ }^{37}$ Possibly, discrepancies in $K_{\text {eq }}$ values could be rationalized by these different atmospheric conditions. Finally, it is noted that, except for some values at low temperatures derived from the measurements in the Arctic winter 1999/ $2000,{ }^{17,37}$ all results reported from field measurements ${ }^{16,17,36,37}$ lie within the uncertainty range of $K_{\text {eq }}$ from the present work.

\section{Conclusions}

The thermal stability of $\mathrm{ClOOCl}$ is studied by photoionization mass spectrometry. The $\mathrm{ClO}-\mathrm{OCl}$ bond dissociation energy is determined, yielding $D^{\circ}{ }_{298}=72.39 \pm 2.8 \mathrm{~kJ} / \mathrm{mol}$. The $\mathrm{ClO}-$ $\mathrm{OCl}$ bond dissociation energy corresponds to an equilibrium constant $K_{\text {eq }}=1.61 \times 10^{-27} \times(T / 300)^{-0.29} \times \exp (8480 / T)$, which is in agreement with previous laboratory experiments ${ }^{12,13}$ and field measurements ${ }^{16,17,36}$ within the given uncertainties. Nonetheless, differences in $K_{\text {eq }}$ within this uncertainty range have already significant implications on the equilibrium partitioning of $\mathrm{ClO}$ and $\mathrm{ClOOCl}$ in the cold dark stratosphere. $K_{\text {eq }}$ reported in this work is in accordance with results from high altitude aircraft measurements, ${ }^{16,17,36}$ and somewhat lower than the value recommended by the current JPL evaluation. ${ }^{34}$ This allows us to exclude the upper uncertainty limit given in ref 34. The present findings imply that $\mathrm{ClOOCl}$ is slightly less stable than previously thought, and consequently, there should be higher $\mathrm{ClO}$ mixing ratios in the cold stratosphere for nighttime conditions than follows from the currently recommended value of $K_{\text {eq. }}$. A lower value of $K_{\text {eq }}$ is expected to shift the partitioning between the $\mathrm{ClO}$ dimer and the $\mathrm{ClO}-\mathrm{BrO}$ cycle toward the latter one, but the overall ozone loss rate in the Arctic winter stratosphere is only marginally affected by this slight change. ${ }^{16,17}$ Reasons for the discrepancies between several field measurements ${ }^{16,17,36}$ and the present results based on laboratory experiments cannot be fully resolved, warranting further laboratory studies and field measurements. Nonetheless, the present work utilizes a novel approach to determine the $\mathrm{ClO}-\mathrm{OCl}$ bond strength, which serves to derive $K_{\text {eq }}$ from laboratory measurements.

Acknowledgment. J.P. acknowledges financial support by the Deutsche Bundesstiftung Umwelt. Financial support by the Bundesministerium für Bildung und Forschung (BMBF), the European Union, and the Fonds der Chemischen Industrie are gratefully acknowledged. The Research Center Jülich greatly appreciates funding for field measurements received from the EC within the THESEO2000 and VINTERSOL programs. The authors acknowledge R. Stimpfle for providing the $\mathrm{ClO}$ and $\mathrm{ClOOCl}$ measurements conducted on board the ER-2 aircraft in winter 1999/2000.

\section{References and Notes}

(1) McGrath, M. P.; Clemitshaw, K. C.; Rowland, F. S.; Hehre, W. J. J. Phys. Chem. 1990, 94, 6126.
(2) Stanton, J. F.; Rittby, C. M. L.; Bartlett, R. J.; Toohey, D. W. J. Phys. Chem. 1991, 95, 2107.

(3) Bloss, W. J.; Nickolaisen, S. L.; Salawitch, R. J.; Friedl, R. R.; Sander, S. P. J. Phys. Chem. A 2001, 105, 11226.

(4) Plenge, J.; Flesch, R.; Kühl, S.; Vogel, B.; Müller, R.; Stroh, F.; Rühl, E. J. Phys. Chem. A 2004, 108, 4859. 39.

(5) Anderson, J. G.; Toohey, D. W.; Brune, W. H. Science 1991, 251,

(6) Solomon, S. Rev. Geophys. 1999, 37, 275.

(7) Molina, L. T.; Molina, M. J. J. Phys. Chem. 1987, 91, 433.

(8) Moore, T. A.; Okumura, M.; Seale, J. W.; Minton, T. K. J. Phys. Chem. A 1999, 103, 1691.

(9) Birk, M.; Friedl, R. R.; Cohen, E. A.; Pickett, H. M.; Sander, S. P. J. Chem. Phys. 1989, 91, 6588.

(10) Peterson, K. A.; Francisco, J. S. J. Chem. Phys. 2004, 121, 2611.

(11) Basco, N.; Hunt, J. E. Int. J. Chem. Kinet. 1979, 11, 649.

(12) Nickolaisen, S. L.; Friedl, R. R.; Sander, S. P. J. Phys. Chem. 1994, $98,155$.

(13) Cox, R. A.; Hayman, G. D. Nature 1988, 332, 796.

(14) Rivière, E. D.; Pirre, M.; Berthet, G.; Renard, J.-B.; Taupin, F. G.; Huret, N.; Chartier, M.; Knudsen, B.; Lefèvre, F. J. Geophys. Res. 2003 108, 8311, DOI: 10.1029/2002JD002087.

(15) Vogel, B.; Müller, R.; Engel, A.; Grooss, J.-U.; Toohey, D. W.; Woyke, T.; Stroh, F. Atmos. Chem. Phys. Discuss. 2005, 5, 1623

(16) von Hobe, M.; Grooss, J.-U.; Müller, R.; Hrechanyy, S.; Winkler, U.; Stroh, F. Atmos. Chem. Phys. 2005, 5, 693.

(17) Stimpfle, R. M.; Wilmouth, D. M.; Salawitch, R. J.; Anderson, J. G. J. Geophys. Res. 2004, 109, DOI:10.1029/2003JD003811.

(18) Flesch, R.; Rühl, E.; Hottmann, K.; Baumgärtel, H. J. Phys. Chem. 1993, 97, 837.

(19) Rühl, E.; Rockland, U.; Baumgärtel, H.; Lösking, O.; Binnewies, M.; Willner, H. Int. J. Mass Spectrom. 1999, 185-187, 545.

(20) Berkowitz, J. Photoabsorption, Photoionization, and Photoelectron Spectroscopy; Acedemic Press: New York, 1979.

(21) Schwell, M.; Jochims, H.-W.; Wassermann, B.; Rockland, U.; Flesch, R.; Rühl, E. J. Phys. Chem. 1996, 100, 10070.

(22) Thorn, R. P., Jr.; Stief, L. J.; Kuo, S.-C.; Klemm, R. B. J. Phys. Chem. 1996, 100, 14178.

(23) Traeger, J. C.; McLoughlin, R. G. J. Am. Chem. Soc. 1981, 103, 3647.

(24) Traeger, J. C. Int. J. Mass Spectrom. 2001, 210/211, 181.

(25) Jacobs, J.; Kronberg, M.; Müller, H. S. P.; Willner, H. J. Am. Chem. Soc. 1994, 116, 1106.

(26) Tomasello, P.; Ehara, M.; Nakatsuji, H. J. Chem. Phys. 2003, 118, 5811.

(27) Li, W. K.; Ng, C. Y. J. Phys. Chem. A 1997, 101, 113.

(28) Rockland, U.; Baumgärtel, H.; Rühl, E.; Lösking, O.; Müller, H. S. P.; Willner, H. Ber. Bunsen-Ges. Phys. Chem. 1995, 99, 969.

(29) Abramowitz, S.; Chase, M. W., Jr. Pure Appl. Chem. 1991, 63, 1449 .

(30) Chase, M. W., Jr. NIST-JANAF Thermochemical Tables. J. Phys. Chem. Ref. Data Monogr. 1998, 9, 1.

(31) McGrath, M. P.; Clemitshaw, K. C.; Rowland, F. S.; Hehre, W. J. Geophys. Res. Lett. 1988, 15, 883.

(32) Lee, T. J.; Rohlfing, C. M.; Rice, J. E. J. Chem. Phys. 1992, 97, 6593.

(33) Zhu, R. S.; Lin M. C. J. Chem. Phys. 2003, 118, 4094

(34) Sander, S. P.; Friedl, R. R.; Golden, D. M.; Kurylo, M. J.; Huie, R. E.; Orkin, V. L.; Moortgat, G. K.; Ravishankara, A. R.; Kolb, C. E.; Molina, M. J.; Finlayson-Pitts, B. J. Suppl. to Eval. No. 14, JPL Publ. 0225, Jet Propulsion Laboratory: Pasadena CA, 2003.

(35) Brune, W. H.; Anderson, J. G.; Chan, K. R. J. Geophys. Res. 1989 , $94,16,649$

(36) Avallone, L. M.; Toohey, D. W. J. Geophys. Res. 2001, 106, 10, 411.

(37) Vogel, B.; Stroh, F.; Grooss, J.-U.; Müller, R.; Deshler, T.; Karhu, J.; McKenna, D. S.; Müller, M.; Toohey, D.; Toon, G. C. J. Geophys. Res. 2003, 108, 8334, DOI: 10.1029/2002JD002564.

(38) Burkholder, J. B.; Orlando, J. J.; Howard, C. J. J. Phys. Chem. 1990, 94, 687.

(39) Brasseur, G.; Solomon, S. Aeronomy of the Middle Atmosphere, Reidel: Dordrecht, The Netherlands, 1986. 